Article

\title{
Technologies, Ethics and Journalism's Relationship with the Public
}

\author{
Megan Duncan ${ }^{1, *}$ and Kathleen Bartzen Culver ${ }^{2}$ \\ ${ }^{1}$ Department of Communication, Virginia Polytechnic Institute and State University, Blacksburg, VA 24061, USA; \\ E-Mail: meganduncan@vt.edu \\ 2 School of Journalism and Mass Communication, University of Wisconsin, Madison, WI 53715, USA; \\ E-Mail: kbculver@wisc.edu \\ * Corresponding author
}

Submitted: 13 March 2020 | Accepted: 28 May 2020 | Published: 27 July 2020

\begin{abstract}
Drones can provide a bird's eye view of breaking news and events that can be streamed live or used in edited news coverage. Past research has focused on the training and ethics of journalists and drone operators. Little attention, however, has been given to audiences and their acceptance and perception of ethics. We suggest that audiences who are open to personal technology use will perceive news media using unmanned aerial vehicles (UAVs) as more ethical in an extension of the Diffusion of Innovation Theory. In a survey $(N=548)$ of adults living in the United States, we explore the correlates between trust, technology, privacy, and the use of UAVs. Results suggest all three are positively correlated with openness toward drone journalism. We find the audience has preferences for the types of news stories that should be covered using drones. Participants indicated they welcome drone journalism when covering traffic and investigative stories, but not celebrities and politicians. The findings have implications for newsrooms, suggesting transparency and outreach to educate people on the technology could help build trust. Further, the results suggest that Diffusion of Innovation theory can be applied when mediated through news media.
\end{abstract}

\section{Keywords}

drones; innovation; journalism; news audiences; unmanned aerial vehicles

\section{Issue}

This article is part of the issue "Journalism from Above: Drones, the Media, and the Transformation of Journalistic Practice" edited by Jonas Harvard (Mid Sweden University, Sweden), Mats Hyvönen (Uppsala University, Sweden) and Ingela Wadbring (Mid Sweden University, Sweden).

(C) 2020 by the authors; licensee Cogitatio (Lisbon, Portugal). This article is licensed under a Creative Commons Attribution 4.0 International License (CC BY).

\section{Introduction}

When then-Kentucky Governor Matt Bevin faced a scandal in 2017 over an exceptionally low tax assessment of his home and property, the Louisville, Kentucky, Fox News affiliate WDRB flew an unmanned aerial vehicle (UAV) over the home during an inspection and subsequent meeting at the home (Andrews, 2017). Bevin was angry and invoked the privacy of his family to argue it was an inappropriate way to cover the news story. At first incorrectly blaming two different news organizations for the drone above, he took to Twitter and called a political reporter a 'peeping Tom': “Drones again flying directly over and around my home filming my children...@wave3news @courierjournal \#PeepingTom Loftus" (Bevin, 2017a).

Soon after, he corrected which news organization was responsible for the UAV, again emphasizing that the UAV was "flying over my home \& filming my children" (Bevin, 2017b) The WDRB news director responded that he was flying the UAV according to federal regulations and did not film the governor's children.

Much of the public is wary of UAVs circling above to capture video and still images. Often citing privacy concerns or suspicion about technology (Tompkins, 2017), about $20 \%$ of Americans say they would be angry or 
scared if they saw a UAV flying near their home (Hitlin, 2017). Audiences may not readily accept drone journalism if they are reluctant to adopt drones as new innovation. Though newsrooms have been criticized for their slow adoption of technology (Garrison, 2001; Roberts \& Saint, 2015), audiences, too, are reticent to accept journalists' use of technology in reporting (Jung, Song, Kim, Im, \& Oh, 2017; Kiousis, 2006; Tsfati, 2010). Diffusion of innovation theory-or the process of learning about and developing an attitude toward an emerging technology (Rogers, 2010)-illuminates the acceptance and openness toward communication technologies like UAV-aided journalism.

Newsrooms adopt new technologies for a variety of reasons, but among the considerations are how journalists think the technology will be received by the audience (Boczkowski, 2004) and how the technology will affect the relationship between journalists and the audience (Ekdale, Singer, Tully, \& Harmsen, 2015). A lack of support of drone journalism from the public could have an impact on UAV adoption in newsrooms or the type of news stories that are covered with the aid of a UAV. Yet, avoiding adopting UAV technology into the newsroom because of audience worries could allow for competitors to gain a foothold in the market of drone news (Christensen, Raynor, \& McDonald, 2015). While drone journalism has been investigated through the lens of legal fights (Goldberg, 2015; Holton, Lawson, \& Love, 2015; McIntyre, 2015), ethical questions for the news industry (Culver, 2014), and technological implications (Gynnild, 2014; Tremayne \& Clark, 2014), this study asks the audience what ethical stances and opinions it has about the use of drones in gathering news. Using the theory of Diffusion of Innovation (Rogers, 2010), we investigate how audience attitudes toward privacy, technology adoption, and journalism ethics influence its openness to drone journalism.

Using a survey of residents of the United States ( $N=548$ ), we measure attitudes toward technology adoption, concerns about privacy, and perception of journalism ethics. We find all three are positively correlated with openness toward drone journalism. The findings have implications for newsrooms considering adopting UAV technology, and for applying Diffusion of Innovation theory to technology mediated by news media.

\section{Literature Review}

\subsection{Public Perceptions of News Media Ethics}

News media in the past decade saw a historic dip in levels of public trust and perception of ethics. A third of Americans ranked the ethical behavior of journalists as high or very high in 2018, ranking above bankers but below accountants (Gallup, 2018). While that percentage seems dismal, it was a 10-point improvement from the public's perception in 2016. The way journalists think of themselves and the way the public thinks of journalists are consistently far apart. The public thinks journalists are motivated by legalities and business competition while journalists feel motivated by professional ethics and personal morals (Voakes, 1997). Journalists think their roles should focus on providing analysis and playing watchdog while audiences think journalists should focus on neutrality and providing basic information (Willnat, Weaver, \& Wilhoit, 2019). Losing the trust of the audience or misunderstanding what the audience expects from the news media can be costly to journalism's business and its credibility. When the audience loses trust in media, it seeks alternative sources of information (Tsfati, 2010).

In times of low media credibility, journalists turn to practices that give their work the appearance of objectivity and neutrality. Drones, or UAVs (also called remotely piloted aircraft), have expanded the ability of journalists to bring images to the audience of news events that journalists cannot get from ground level, including those of natural disasters like Alabama tornados in 2011 (Estes, 2011), a comprehensive view of Occupy Wall Street protests that same year (Gynnild, 2014), celebrities vacationing on the beach (Tremayne \& Clark, 2014), and investigative journalism (Chamberlain, 2017; Tremayne \& Clark, 2014), like WDRB's look at Bevin's home. Images of events lend to journalists' credibility and an appearance of objectivity (Zelizer, 2010). When journalists complement textual narratives with visual accounts through photographs or video, the audience stands to benefit because members can see for themselves evidence of the narrative told by the news media. By providing 'indisputable images,' journalists can bolster the trust of the audience and reduce the room for claims of bias, hopefully retaining the audience.

\subsection{Introduction of Drones into Journalism}

When newsrooms and journalism schools first started adopting UAVs for reporting, best practices, ethics, and the laws surrounding them were ambiguous. Some journalists and journalism educators like Matt Waite of the University of Nebraska saw the ability to capture still and video images from above the treetops as an exciting innovation with potential to improve visual journalism with less safety risk and cost than a news helicopter (Culver, 2014). Soon though, Waite and others were sent cease-and-desist letters and told they must get a small aircraft pilot's license. Though he did, those rules were clearly a burden on newsrooms, and the Federal Aviation Administration revised them in 2016. This new rule, called the Small Unmanned Aircraft Rule or Part 107-established a separate certification process for commercial drone operators. Journalists, who are considered commercial under the regulations, had a new path to using UAVs in journalism that involved taking a knowledge test but no operation test (Federal Aviation Administration, 2016). 
While the regulations primarily addressed the law, they also set some ethical guardrails for newsrooms and other drone operators who were working at the boundaries. For example, ethicists argued that remote drone operation could lead to dehumanization through gamification and offer a limited field of vision that would reduce safety compared to visual lineof-sight operation (Culver, 2014). The Federal Aviation Administration regulations made line-of-sight operation mandatory. Additionally, the regulations emphasize bystander safety by prohibiting drone operation over people and crowds and operating after dark (Federal Aviation Administration, 2016). For situations where personal and professional ethics have failed to catch up to technology innovations, these regulations may provide the baseline for ethical decision making in newsrooms.

\subsection{UAVs and Early Technology Adoption}

UAVs represent an innovation in the journalism market. According to diffusion of innovation theory (Rogers, 2010), the innovation itself generally holds the characteristics of an improvement over past technology, providing a market need, and visibility (Rogers, 2010). From a news organization's perspective, UAVs provide this by offering a low-cost, easy-to-use alternative to news helicopters (Culver, 2014; Tremayne \& Clark, 2014) that is visible to mass audiences when the footage is shown on television or streamed online. Hence, the adoption of UAVs for journalism purposes has been studied from the perspective of early newsroom adopters (Belair-Gagnon, Owen, \& Holton, 2017). Here, though, we take the perspective of the audience through the lens of diffusion of innovation theory. This is a slight departure from the original intention of the theory, as we are not focused on the audience's use of the technology directly, but rather its buyin and openness toward journalistic reporting that uses the technology. It is an indirect adoption of the technology that is rewarded not by purchases but rather views and granting of credibility.

Diffusion of innovation theory approaches the proliferation (or failure) of new technology through social systems as a process that begins with knowledge, and progresses through interest, persuasion, adoption and confirmation (Rogers, 2010). The first step toward adoption of a technology is knowledge about it. Thus, communication systems are key to spreading initial knowledge and subsequent information that leads to persuasion (Rogers, 2010). It likely did not help public trust of drones that in the years after September 11, 2001, many audiences first heard of drones in the context of military reconnaissance and warfare (Tremayne \& Clark, 2014). Yet, news organizations are in the unique position of having direct access to a mass audience to which to communicate knowledge about the innovation.

In any diffusion of innovation, some people are willing to adopt the technology in the early stages where there are risks and higher costs, while laggards are con- tent to wait until the technology is widely adopted and the costs and risks have diminished (Rogers, 2010). This openness to early adoption of a technology compared to peers and wider society defines an individual's 'innovativeness' (Rogers \& Shoemaker, 1971). Early adopters of innovation tend to have consistent attitudes toward openness to technology. Research into adoption of communication technologies has demonstrated that those who were among the first to adopt digital television were more likely to have been early adopters of email, for example (Atkin, Neuendorf, Jeffres, \& Skalski, 2003). Early adoption of fax technology was more strongly predicted by these attitudes toward technology than social and demographic factors (Neuendorf, Atkin, \& Jeffres, 1998).

Past research into the adoption of communication technologies has used these attitudes toward technology and past early adoption behavior as predictors of direct adoption of a technology. Yet, this variable was such a strong predictor of early adoption in these cases, we posit that the theory of Diffusion of Innovation will work similarly for a case of indirect adoption. Thus, we hypothesize that those with early adopter attitudes toward technology will be more open to the adoption and use of drones in journalism:

H1: Audiences who adopt technology earlier will be more open to drone journalism.

\subsection{Privacy and Technology Innovation}

A chief concern among those who fear technology diffusion may be the loss of privacy. When online journalism emerged in the market, audiences were wary of their privacy. And, indeed, Culver (2014) identified privacy of those who were surveilled as one of four main ethical concerns drone operators should consider. The author's research found that drone developers had no clear ethical principles on which their decisions about the privacy of those on the ground were made. Instead, the developers defaulted to legal definitions, and referenced the conception of "reasonable expectation of privacy" (Culver, 2014, p. 59). While eyewitness accounts hold strong value in journalism, drone journalism becomes a form of a digitized robot eyewitness that transforms the norms of journalism (Gynnild, 2014). Tremayne and Clark (2014) argued that while surveillance is one of the key functions of journalism, journalists need to address the ethical boundary between violating citizens' privacy and getting the best story. They called for a balance between using drone journalism to paint a more realistic version of reality and transforming the outdoors into a Foucauldian panopticon. Gynnild and Uskali (2018) poses the question: Where should journalists never fly drones in respect of privacy?

If journalists are conflicted and unclear about the ethical policies surrounding UAVs, it follows that the audience may not have confidence in journalists to respect their privacy. While it is true that much of the Digital 
Age has been about giving up various forms of privacy, Gynnild and Uskali (2018) argue that recent pushback on technology giants from the public demonstrate the public still cares about and expects privacy. There's little research on where the American public thinks journalists should and should not fly UAVs. A 2017 Pew Research poll, though, shines light on the public's thoughts about drones in general. More than half of Americans think drones should not be flown near people's homes, but $44 \%$ were accepting of drones in public parks (Hitlin, 2017). These results suggest that the public has concerns about privacy. We suggest that this concern will be extended to UAVs flown by journalists, and that support for drone journalism will decrease as personal concerns about privacy increase:

H2: Audiences more concerned with privacy will be less open to drone journalism.

\subsection{Media Ethics and Technology Innovation}

Early adoption of online communication technologies was predicated on the amount of social trust (Mutz, 2005). Because the systems were new and most of their workings were behind a black box, the public needed some blind trust that people they could not see or talk to would act ethically with their credit card numbers, for example (Mutz, 2005). While research has found gaps between how the audience thinks about journalism ethics and how journalists think (Tsfati, Meyers, \& Peri, 2006; Voakes, 1997), audience members rank journalistic values as high priorities when it comes to earning their trust (Chung, 2009; Heider, McCombs, \& Poindexter, 2005; Van Der Wurff \& Schoenbach, 2014). Trust in news workers to act ethically and without bias is a consistent predictor of news media use (Tsfati, 2010; Tsfati \& Cappella, 2003). Similarly, perceived credibility of online news is positively related with its use (Johnson \& Kaye, 1998, 2004; Wanta \& Hu, 1994):

H3: Audiences who think news media act ethically will be more open to drone journalism.

In it its infancy, citizen journalism was an alternative for audiences who had low trust in media ethics. Audience perception of mainstream news trust predicted use of early online mainstream news use so that those who had greater trust in mainstream media were more likely to use mainstream media online (Tsfati, 2010; Tsfati \& Cappella, 2003). Those who had distrust in mainstream news were the early users of citizen blogs, which they saw as an alternative source of information (Johnson \& Kaye, 2009). Because audiences with low media trust turned to citizen alternatives in past communication innovations, we hypothesize that those who have low perceptions of media ethics will support civilian UAV use more than journalism UAV use:
H4: Audiences who have a low perception of news ethics will support drone use by civilians more than journalists.

\section{Method}

In a survey $(N=548)$ of adults living in the United States, we explore the correlates between concern about privacy, attitude toward technology adoption, and perception of news media ethics with the audience's openness to drone journalism. The survey was distributed through Survey Sampling International, and participants were paid incentives for participating through their agreement.

\subsection{Participants}

The sample of survey respondents was drawn from across the United States and designed to approximate a nationally representative sample. Participants were $51 \%$ female; the average household salary was $\$ 50,000$ to $\$ 59,000$; and the average participant had a twoyear post-secondary degree. Where participants were allowed to select more than one race, $82 \%$ indicated they were white; $11 \%$ black or African-American; and $5 \%$ Asian. About $9 \%$ of the sample indicated their ethnicity was Hispanic. The average age was between 35 and 44 years old.

\subsection{Procedure}

Participants double opted-into the survey by first agreeing to be included on Survey Sampling International's email list to participate in surveys. Then, they chose to participate in this survey in exchange for incentives as outlined by their agreement with Survey Sampling International. Once participants were screened for the age of majority, they were shown an information sheet about this research study. Those who consented to the information sheet continued to the survey, which took on average 18 minutes to complete. Participants were asked about their use of, attitudes toward, and engagement with news media. Then, they were given the following information statement before they began answering drone questions:

The United States is writing rules for civilians to use Unmanned Aerial Vehicles (often referred to as drones) in the National Airspace. This will include recreational use by hobbyists, as well as some commercial uses like capturing video to use in movies. Some news organizations are interested in using these technologies in their reporting to take photos, capture video or sense data. We'd like to hear what you think about this topic.

After answering questions about drone use, participants indicated their demographic and sociographic information before concluding the survey. 


\subsection{Variable Construction}

\subsubsection{Technology Adoption}

Technology adoption ( $M=2.95, S D=1.25)$ was measured using Chau and Hui's (1998) index of eight items to measure early adoption of information technology products. These eight items were measured on a scale of 1 to 5 where 1 indicated avoidance of early adoption and 5 indicated early adoption. The answers to the items were averaged so that higher values on the resulting variable indicated earlier adoption of technology. The Cronbach's alpha of the eight items was .97 (Table 1).

\subsubsection{Privacy Concern}

Privacy concern $(M=4.08, S D=0.78)$ was measured using a four-item index adapted from the Internet Users Information Privacy Concern scale (Malhotra, Kim, \& Agarwal, 2004) that included 'Privacy is important to me,' 'I worry new technology is a threat to privacy,' 'Compared with other subjects on my mind, personal privacy is very important,' and 'I am concerned with threats to my personal privacy today.' The questions were asked on a 1 to 5 scale, where 1 was strongly disagree and 5 was strongly agree. The items were averaged so that higher numbers on the resulting variable indicate stronger concerns about privacy. The Cronbach's alpha for the four items was 0.81 (Table 2).

\subsubsection{Media Ethics}

Perception of media ethics ( $M=2.90, S D=1.92$ ) was measured using an eight-item scale based on the ethical principles of journalism. The items asked the participants to rate how well most news media organizations do at meeting the ethical principles such as 'seek the truth and report it' and 'be accountable' on a scale of 1 to 5 where 1 was strongly disagree and 5 was strongly agree. The items were averaged so that higher values on the resulting variable indicate a higher perception of media ethics. The Cronbach's alpha for the eight items was 0.94 (Table 3).

\subsubsection{Openness to Drone Journalism}

Openness to drone journalism $(M=3.71, S D=.83)$ was measured by support for 11 types of news stories that have been covered using UAVs to capture images on a 1 to 5 scale where 1 indicated not open to that type of drone journalism story and 5 indicated very open to that type of drone journalism story. These included weather, breaking news, celebrity events and investigative stories and were shown in randomized order. The Cronbach's alpha for these 11 items was 0.92 . The items were averaged so that higher values on the resulting scale indicate more openness toward drone journalism. For a complete list of the 11 types of stories included in this variable, see Table 4.

Table 1. Means of early technology adoption by scale item.

\begin{tabular}{|c|c|c|}
\hline Variable & $M$ & $S D$ \\
\hline I often seek out information about new hardware/software products & 3.21 & 1.38 \\
\hline When I go hardware/software shopping, I find myself spending a lot of time checking out new products & 3.01 & 1.35 \\
\hline I like to go to places where I will be exposed to information about new hardware/software products & 2.98 & 1.36 \\
\hline I like magazines that introduce new hardware/software products & 2.94 & 1.39 \\
\hline I frequently look for new hardware/software products & 2.93 & 1.39 \\
\hline I take advantage of the first available opportunity to find out about new hardware/software products & 2.86 & 1.38 \\
\hline I am continually seeking new hardware/software product experiences & 2.85 & 1.39 \\
\hline $\begin{array}{l}\text { I seek out situations in which I will be exposed to new and different sources of new } \\
\text { hardware/software products }\end{array}$ & 2.84 & 1.38 \\
\hline
\end{tabular}

Notes: The resulting variable of the eight-item scale $(M=2.95, S D=1.25)$ has a Cronbach's alpha of .97. Source: Based on Chau and Hui's (1998) early technology adoption scale.

Table 2. Means of privacy concerns by scale item.

\begin{tabular}{lcc}
\hline Variable & $M$ & $S D$ \\
\hline Privacy is important to me & 4.38 & 0.89 \\
Compared with other subjects on my mind, personal privacy is very important & 4.09 & 0.97 \\
I worry new technologies are a threat to privacy & 3.95 & 1.01 \\
I am concerned about threats to my personal privacy today & 3.89 & 1.04 \\
\hline
\end{tabular}

Notes: The resulting variable of the 4-item index $(M=4.08, S D=.78)$ has a Cronbach's alpha of .811. Items based on the Internet Users Information Privacy Concerns scale (Malhotra et al., 2004). 
Table 3. Means of perception of media ethics by scale item.

\begin{tabular}{lcc}
\hline Variable & $M$ & $S D$ \\
\hline Provide the audience with information they need to know & 3.17 & 1.20 \\
Engage with communities & 3.16 & 1.12 \\
Seek the truth and report it & 3.01 & 1.26 \\
Be accountable (e.g., correct errors or listen to feedback) & 2.93 & 1.16 \\
Minimize harm & 2.79 & 1.20 \\
Be transparent (e.g., disclose reporting processes and ethical choices) & 2.78 & 1.22 \\
Act independently and avoid outside influence & 2.71 & 1.28 \\
Minimize bias & 2.65 & 1.24 \\
\hline
\end{tabular}

Note: The resulting variable of the eight-item index $(M=2.90, S D=1.02)$ has a Cronbach's alpha of .94.

Table 4. Means of openness to drone journalism by index item.

\begin{tabular}{lcc}
\hline Variable & $M$ & $S D$ \\
\hline Cover severe weather events, such as a hurricane & 4.15 & 1.01 \\
Monitor possible environmental damage, such as rising sea levels & 4.07 & 1.02 \\
Monitor traffic congestion, such as a live feed during rush hour & 4.03 & 1.04 \\
Get video from breaking news involving a hazardous incident, such as a fire & 3.96 & 1.04 \\
Do investigative reporting, such as a long-term look traffic safety in an area & 3.93 \\
Cover a story on the outdoors, such as best places to rock climb & 3.90 & 1.05 \\
Show raw footage of events live as they happen, such as high-speed police chases & 3.63 \\
Report on civilian protests, such as the Occupy movement & 3.62 & 1.10 \\
Get video of breaking news involving a crime, such as a mass shooting & 3.60 \\
Cover celebrity events, such as a wedding & 1.14 \\
Document impropriety by well-known figures, such as a politician having an extramarital affair & 2.95 \\
\hline
\end{tabular}

Note: The resulting variable of the 11-item index $(M=3.71, S D=.83)$ has a Cronbach's alpha of .918 .

\subsubsection{Civilian/Journalist UAV Support Gap}

Civilian/journalist UAV support gap $(M=-.09, S D=1.07)$ captured the extent to which a participant supported UAV use by civilians more than by journalists. This was done by calculating the difference between participants' answers to the statements: 'I support civilian UAV (drone) use' ( $M=3.34, S D=1.20)$ and 'I support use of UAVs (drone) for journalism' $(M=3.43, S D=1.21)$. Each statement was measured on a scale of 1 to 5 where 1 was strongly disagree and 5 was strongly agree. In the resulting variable, a number above zero indicated stronger support for civilian use than for journalism use while a number below zero indicated stronger support for journalist use than for civilian use.

\section{Results}

\subsection{Descriptive Results}

A repeated measures test was used to compare the 11 drone journalism story types that compose the Openness to Drone Journalism index. When Bonferroni's correction was applied, there were significant differences in support for many of the story types. For example, audiences were significantly more open to journalists using UAVs to cover weather than traffic $(M D=.12$, $S E=.03), p=.015$; hazards $(M D=.21, S E=.04)$, $p=<.001$; investigations $(M D=.25, \mathrm{SE}=.04), p<.001$; outdoors $(M D=.52, S E=.05, p<.001$; live events $(M D=.52, S E=.04), p<.001$; protests $(M D=.52$, $S E=.04), p<.001$; celebrity events $(M D=1.14, S E=.06)$, $p<.001$; or impropriety $(M D=1.2, S E=.07), p<.001$ (Figure 1).

A paired-sample t-test was used to compare the support for civilian $(M=3.34, S D=1.20)$, and journalist use of UAVs $(M=3.43, S D=1.21)$. The results indicate that the difference $(M D=-.09)$ rose to a level of significance so that there was stronger support for use of UAVs for journalism than by civilians, $t(547)=-2.00, p=.046$.

\subsection{Controls}

Demographic and sociographic characteristics have been shown to be associated with both trust in news media and news use habits. For example, age and income are 


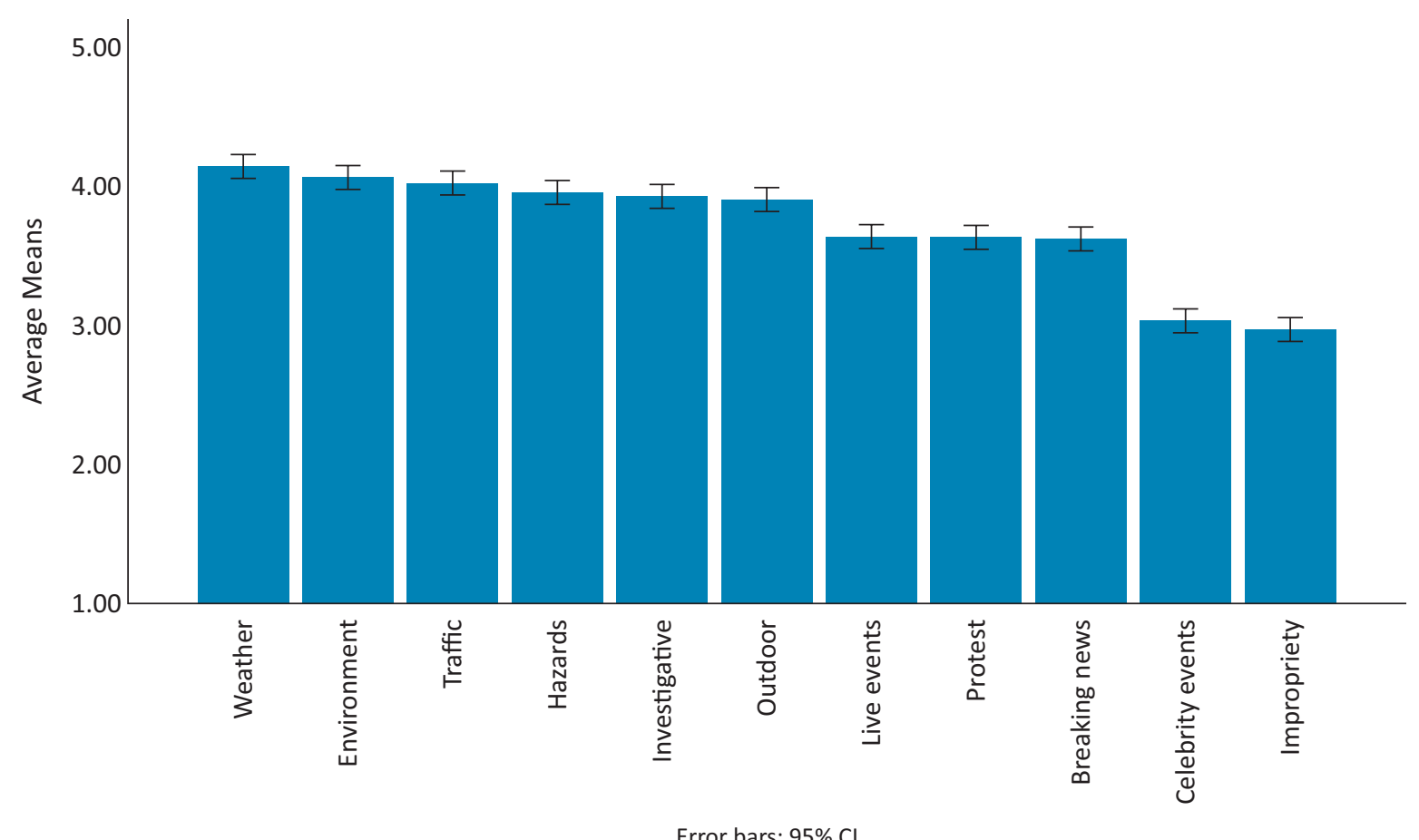

Figure 1. Differences of means of drone story type items. Note: Findings indicate there is significantly more openness toward using UAVs for covering weather, environment and traffic stories than covering celebrity events or impropriety.

positively associated with news seeking behavior (Gil de Zúñiga \& Hinsley, 2013; Ksiazek, Malthouse, \& Webster, 2010). Similarly, youth and higher incomes are associated with earlier adoptions of technologies (Rogers, 2010). Meanwhile, political conservatives are less likely to have trust in news media than are liberals (Lee, 2010; Stroud \& Lee, 2013). To isolate the variables of interest, age, gender, race, income, and political ideology were controlled for in the model.

\subsection{Hypotheses Testing}

The first three hypotheses were tested using an Ordinary Least-Squares regression model. Openness to drone journalism was used as the outcome variable. Attitude toward technology adoption, privacy concerns, and perception of news ethics were used as independent variables. Age, income, race, gender, and ideology were included in the model as controls. The results of the regression indicated the model was significant (adjusted $\left.R^{2}=.21, F(9,547)=17.42, p<.001\right)$. The three independent variables together explained $20 \%$ of the variance and explained significantly more variance than the control variables alone (adjusted $R^{2}=.20, F(3,538)=47.07$, $p<.001)$. Each of the independent variables was positively correlated with the dependent variable to a level of significance: attitude toward technology adoption $(\beta=.18, p<.001)$, privacy concerns $(\beta=.15, p<.001)$, and perception of media ethics $(\beta=.346, p<.001)$. These results provide support for $\mathrm{H} 1$ and $\mathrm{H} 3$, which suggested that those who are more open to adopting technology and those who perceive the news media to act ethically will be more open to drone journalism. There is no evidence to support $\mathrm{H} 2$, which suggested that those more concerned about privacy would be less open to drone journalism. While the variable is a significant predictor of openness to drone journalism, the relationship is positive, not negative (Table 5 ).

To test the final hypothesis, which suggested that those who have a low perception of news ethics will support drone use by civilians more than by journalists, an Ordinary Least-Squares regression used the same model as the previous one. The dependent variable in this model was the civilian/journalist UAV support gap. The results of the regression indicated the model was significant (adjusted $R^{2}=.04, F(9,547)=3.45, p<.001$ ). Perception of media ethics explained $3 \%$ of the variance and explained significantly more variance than the control variables, privacy concerns and technology adoption together (adjusted $R^{2}=.01, F(1,538)=14.76, p<.001$ ). Perception of media ethics was negatively correlated with the civilian/journalist UAV support gap $(\beta=.18$, $p<.001)$. The model also indicates that early tech adoption was positively correlated with the civilian/journalist UAV support gap $(\beta=.15, p<.004)$. These results provide support for $\mathrm{H} 4$, suggesting that the less people perceive the media as ethical the more they support civilian use of UAVs compared to journalistic use (Table 6).

\section{Discussion}

These findings shed light on an understudied area of drone journalism: The audience's perspective. We find that the audience is more likely to support some types 
Table 5. The influence of privacy concerns, early technology adoption and perception of media ethics on the openness to civilian drone use.

\begin{tabular}{lcccc}
\hline & \multicolumn{3}{c}{ Openness to drone journalism } \\
\cline { 2 - 5 } & SE & $B$ & $t$ & \multicolumn{1}{c}{$p$} \\
\hline Constant & 0.25 & & 02 & 0.001 \\
Age & 0.02 & 0.02 & 1.66 & 0.58 \\
Gender (Female =1) & 0.07 & 0.07 & 0.78 & 0.098 \\
Race (White = 1) & 0.09 & 0.03 & 0.77 & 0.434 \\
Income & 0.01 & 0.04 & -0.27 & 0.442 \\
Education & 0.02 & -0.01 & -0.37 & 0.788 \\
Political ideology & 0.04 & -0.02 & 3.72 & 0.712 \\
Tech adoption & 0.03 & 0.18 & 3.77 & $<.001$ \\
Privacy concern & 0.04 & 0.15 & 8.15 & $<.001$ \\
Media ethics & 0.04 & 0.35 & & $<.001$ \\
$N=548$ & & & Adj. $R^{2}=.213$ &
\end{tabular}

of drone journalism stories than others. For example, we find high support for coverage of severe weather events and low support for documenting impropriety by public figures. While overall, we observe openness to drone journalism from the public, we find that concerns about privacy, attitudes toward technology and perception of media ethics are all significant predictors of the audience's openness to drone journalism.

Fundamentally, audiences who perceive news media to act ethically, who are concerned about privacy, and who are early technology adopters are more open to drone journalism. This provides evidence that those who see the benefits of technology and believe that news media take professional ethics seriously will support the use of UAVs in news reporting. Interestingly, the correlation between privacy concerns and openness to drone journalism is positive. This suggests that in this case, those who have personal privacy top of mind are open to drone journalism, while prior research suggests that those who are more concerned about privacy will be less likely to accept new communication technologies.
Additionally, we find a negative correlation between the perception of media ethics and the civilian/journalist UAV support gap. As the audience's perception of media ethics decreases, the support for civilian drones increases in comparison to the support for drone journalism. When audiences do not think news media act ethically, they are less supportive of journalists using drones. This is similar to past literature that suggests those distrustful of journalism are more likely to turn to alternative sources of information during innovative periods (Johnson \& Kaye, 2009).

\subsection{Limitations}

While this study provides evidence to understand the audience's perspective on drone journalism, it does have some limitations. Chief among these is causation. Like any survey, we are unable to say that concerns about privacy, early technology adoption, or perception of ethics are the cause of openness to drone journalism or support of civilian drone use compared to drone journalism.

Table 6. The influence of privacy concerns, early technology adoption and perception of media ethics on the support gap between civilian UAV use and journalist UAV use.

\begin{tabular}{lcccc}
\hline & \multicolumn{4}{c}{ Support for civilian UAV use over drone journalism } \\
\cline { 2 - 5 } & SE & $B$ & $t$ & $p$ \\
\hline Constant & 0.35 & & -1.02 & 0.043 \\
Age & 0.03 & -0.07 & -1.07 & 0.11 \\
Gender (Female = 1) & 0.1 & -0.05 & -1.98 & 0.283 \\
Race (White = 1) & 0.12 & -0.09 & -0.28 & 0.048 \\
Income & 0.02 & -0.01 & -0.06 & 0.777 \\
Education & 0.03 & -0.00 & 0.27 & 0.955 \\
Political ideology & 0.06 & 0.01 & -0.87 & 0.788 \\
Privacy concern & 0.06 & -0.04 & 2.87 & 0.385 \\
Tech adoption & 0.05 & 0.15 & -3.84 & 0.004 \\
Media ethics & 0.05 & -0.18 & Adj. $R^{2}=.04$ & $<01$ \\
$N=548$ & & & & \\
\hline
\end{tabular}


Hence, these results should be understood as influencing factors.

Second, while the survey pool was designed to be representative of the United States Census, racial and ethnic minorities were underrepresented. While the Census indicates $13 \%$ Black or African-American, our sample included only $11 \%$. Additionally, while $18 \%$ of the population is Hispanic, our sample included only $9 \%$. The underrepresentation of these groups in our sample could alter results in comparison to the general population.

Finally, audiences are exposed to and learn more about drones with each passing natural disaster or highspeed car chase. These results described here, which are from data collected in July 2016, may change as drones are seen as less novel.

\subsection{Practical Implications}

Gynnild (2014) suggested that the theory of diffusion of innovation might not go far enough to fully explain the impact UAVs could have on journalism. She posited that drone journalism qualified as a case deserving of a look through the lens of 'disruptive innovation.' Disruptive innovation theory (Bower \& Christensen, 1995) applies to instances where market incumbents ignore a technological innovation by market challengers to the incumbent's eventual peril. Economists laid out a thorough case that the struggle between legacy news media and new media fit the profile of a disruptive innovation (Christensen, Skok, \& Allworth, 2012). In disruptive innovations, incumbents spend too much time paying attention to current customers who want the status quo rather than the innovation on the horizon. Hence, news organizations who pay too much attention to audiences who are distrustful of drone journalism will pay a cost to challengers who innovate regardless of current audience preferences.

Rather than interpreting these results as evidence that playing it safe is preferable, we suggest newsrooms and journalists see these results as evidence that educating the audience will help them accept and support newsroom innovation. For example, participants said news media were doing poorly on transparency. Building a relationship with the audience that does more to disclose how the news story was crafted builds news credibility (Curry \& Stroud, 2019). Newsrooms that engage with the audience to demonstrate how its privacy will be respected and how it will decide and enforce the boundaries of ethics should increase the audience's openness to innovation. This will allow newsrooms to both keep current audience members and grow it to those who are looking for that innovation to change their news experience.

\subsection{Theoretical Implications}

In the past, the theory of diffusion of innovation (Rogers, 2010) has provided guidance to researchers about who will be open to using a wide variety of technologies, including many online and digital communication technolo- gies. In this study, we expand the theory to look at how early adopters are more open to an innovation that they do not directly use but would benefit from through a relationship with a news organization. This new perspective on the theory suggests that those who avoid early adoption of technologies are also less willing to see newsrooms adopt technologies that could improve the information they get. This framework should be examined in the context of other early-stage innovations to understand its generalizability. We see this as a potentially important theoretical contribution to understanding why legacy media lag behind their new media counterparts in news innovation.

Additionally, we find supporting evidence for a past trend: Those who have low trust in news media turn to non-journalists during periods of journalism innovation. In the early days of the internet, these low-mediatrust users turned to citizen blogs (Johnson \& Kaye, 2009). Here, those with low perceptions of media ethics were more trusting of civilians using drones, who are not necessarily certified by the Federal Aviation Administration for safety and knowledge, than journalists, who presumably are certified. Future research should examine whether the audience's knowledge about the certification process journalists must complete elevates the audience's trust in journalists to operate drones. Capturing a measure of media cynicism may also shed some light on this finding.

\section{Conclusion}

Taken together, the results provide a way forward for newsrooms looking to adopt new technology and build relationships with the audience. First, they should work to educate the audience on ethical practices of the news organization, perhaps through a transparent policy posted online or through community events. That ethical policy should be clear about the boundaries of privacy for private citizens, celebrities, and public officials. Second, newsrooms should educate the audience about how the technology works so that late-adopters are less concerned about the technology's implications. The findings provide avenues for theoretical exploration between generalized audience trust in news media and its trust in newsroom technology.

\section{Conflict of Interests}

The authors declare no conflict of interests.

\section{References}

Andrews, T. (2017). Why a TV station flew a drone over Kentucky Governor's home. The Washington Post. Retrieved from https://www.washingtonpost.com/ news/morning-mix/wp/2017/08/02/why-a-tvstation-flew-a-drone-over-kentucky-governorshome/?noredirect=on 
Atkin, D. J., Neuendorf, K., Jeffres, L. W., \& Skalski, P. (2003). Predictors of audience interest in adopting digital television. The Journal of Media Economics, 16(3), 159-173.

Belair-Gagnon, V., Owen, T., \& Holton, A. E. (2017). Unmanned aerial vehicles and journalistic disruption: Perspectives of early professional adopters. Digital Journalism, 5(10), 1226-1239.

Bevin, M. [GovMattBevin]. (2017a, August 1). Drones again flying directly over and around my home filming my children...@wave3news@ @courierjournal \#PeepingTom Loftus [Tweet]. Retrieved from https://twitter.com/GovMattBevin/status/ 892408375723651072

Bevin, M. [GovMattBevin]. (2017b, August 1). The drone that was just flying over my home \& filming my children was personally flown by @WDRBNews Director [Tweet]. Retrieved from https://twitter.com/ GovMattBevin/status/892417511303655424

Boczkowski, P. J. (2004). The processes of adopting multimedia and interactivity in three online newsrooms. Journal of Communication, 54(2), 197-213.

Bower, J. L., \& Christensen, C. (1995). Disruptive technologies: Catching the wave. Harvard Business Review. Retrieved from https://hbr.org/1995/01/ disruptive-technologies-catching-the-wave

Chamberlain, P. (2017). Drones and journalism (Vol. 4). Abingdon: Taylor \& Francis.

Chau, P. Y., \& Hui, K. L. (1998). Identifying early adopters of new IT products: A case of Windows 95. Information \& Management, 33(5), 225-230.

Chamberlain, P. (2017). Drones and journalism (Vol. 4). Abingdon: Taylor \& Francis.

Christensen, C., Raynor, M., \& McDonald, R. (2015). What is disruptive innovation? Harvard Business Review. Retrieved from https://hbr.org/2015/12/whatis-disruptive-innovation

Christensen, C., Skok, D., \& Allworth, J. (2012, September 15). Breaking news: Mastering the art of disruptive innovation in journalism. Nieman Reports. Retrieved from http://niemanreports.org/articles/ breaking-news

Chung, D. S. (2009). How readers perceive journalists' functions at online community newspapers. Newspaper Research Journal, 30(1), 72-80.

Culver, K. B. (2014). From battlefield to newsroom: Ethical implications of drone technology in journalism. Journal of Mass Media Ethics, 29(1), 52-64.

Curry, A. L., \& Stroud, N. J. (2019). The effects of journalistic transparency on credibility assessments and engagement intentions. Journalism. https://doi.org/ $10.1177 / 1464884919850387$

Ekdale, B., Singer, J. B., Tully, M., \& Harmsen, S. (2015). Making change: Diffusion of technological, relational, and cultural innovation in the newsroom. Journalism \& Mass Communication Quarterly, 92(4), 938-958.

Estes, A. C. (2011). Should News Corp. be trusted with a flying robot camera? The Atlantic Wire. Retrieved from http://www.theatlanticwire.com/national/ 2011/08/should-news-corp-be-trusted-flying-robotcamera/40751/\#

Federal Aviation Administration. (2016). Summary of small unmanned aircraft rule (part 107). Washington, DC: Federal Aviation Administration. Retrieved from https://www.faa.gov/uas/media/Part 107_Summary.pdf

Gallup. (2018). Honesty/ethics in professions. Gallup. Retrieved from https://news.gallup.com/poll/1654/ honesty-ethics-professions.aspx

Garrison, B. (2001). Diffusion of online information technologies in newspaper newsrooms. Journalism, 2(2), 221-239.

Gil de Zúñiga, H., \& Hinsley, A. (2013). The press versus the public: What is "good journalism?" Journalism Studies, 14(6), 926-942.

Goldberg, D. (2015). Dronalism: Journalism, remotely piloted aircraft, law and regulation. FIU Law Review, 10(2). https://dx.doi.org/10.25148/lawrev.10.2.8

Gynnild, A. (2014). The robot eye witness: Extending visual journalism through drone surveillance. Digital Journalism, 2(3), 334-343.

Gynnild, A., \& Uskali, T. (Eds.). (2018). Responsible drone journalism. London: Routledge.

Heider, D., McCombs, M., \& Poindexter, P. M. (2005). What the public expects of local news: Views on public and traditional journalism. Journalism \& Mass Communication Quarterly, 82(4), 952-967.

Hitlin, P. (2017). 8\% of Americans say they own a drone, while more than half have seen one in operation. Pew Fact Tank. https://www.pewresearch.org/facttank/2017/12/19/8-of-americans-say-they-owna-drone-while-more-than-half-have-seen-one-inoperation/ft_17-12-19_drones_aboutoneinten

Holton, A. E., Lawson, S., \& Love, C. (2015). Unmanned aerial vehicles: Opportunities, barriers, and the future of "drone journalism." Journalism Practice, 9(5), 634-650.

Johnson, T. J., \& Kaye, B. K. (1998). Cruising is believing? Comparing Internet and traditional sources on media credibility measures. Journalism \& Mass Communication Quarterly, 75(2), 325-340.

Johnson, T. J., \& Kaye, B. K. (2004). Wag the blog: How reliance on traditional media and the Internet influence credibility perceptions of weblogs among blog users. Journalism \& Mass Communication Quarterly, 81(3), 622-642.

Johnson, T. J., \& Kaye, B. K. (2009). In blog we trust? Deciphering credibility of components of the internet among politically interested internet users. Computers in Human Behavior, 25(1), 175-182.

Jung, J., Song, H., Kim, Y., Im, H., \& Oh, S. (2017). Intrusion of software robots into journalism: The public's and journalists' perceptions of news written by algorithms and human journalists. Computers in Human Behavior, 71, 291-298.

Kiousis, S. (2006). Exploring the impact of modality on 
perceptions of credibility for online news stories. Journalism Studies, 7(2), 348-359.

Ksiazek, T. B., Malthouse, E. C., \& Webster, J. G. (2010). News-seekers and avoiders: Exploring patterns of total news consumption across media and the relationship to civic participation. Journal of Broadcasting \& Electronic Media, 54(4), 551-568.

Lee, T. T. (2010). Why they don't trust the media: An examination of factors predicting trust. American Behavioral Scientist, 54(1), 8-21.

Malhotra, N. K., Kim, S. S., \& Agarwal, J. (2004). Internet users' information privacy concerns (IUIPC): The construct, the scale, and a causal model. Information Systems Research, 15(4), 336-355.

McIntyre, K. (2015). How current law might apply to drone journalism. Newspaper Research Journal, 36(2), 158-169.

Mutz, D. C. (2005). Social trust and e-commerce: Experimental evidence for the effects of social trust on individuals' economic behavior. Public Opinion Quarterly, 69(3), 393-416.

Neuendorf, K. A., Atkin, D., \& Jeffres, L. W. (1998). Understanding adopters of audio information innovations. Journal of Broadcasting \& Electronic Media, 42(1), 80-93.

Roberts, C., \& Saint, K. (2015). A slow response to quick response: Diffusion of QR technology on US newspaper front pages. Journalism \& Mass Communication Quarterly, 92(1), 39-55.

Rogers, E. M. (2010). Diffusion of innovations. New York, NY: Simon and Schuster.

Rogers, E. M., \& Shoemaker, F. F. (1971). Communication of innovations; A cross-cultural approach. New York, NY: Free Press.

Stroud, N. J., \& Lee, J. K. (2013). Perceptions of cable news credibility. Mass Communication and Society,
16(1), 67-88.

Tompkins, A. (2017). The 2018 drone journalism forecast. Poynter. Retrieved from https://www.poynter.org/ tech-tools/2017/the-2018-drone-journalismforecast

Tremayne, M., \& Clark, A. (2014). New perspectives from the sky: Unmanned aerial vehicles and journalism. Digital Journalism, 2(2), 232-246.

Tsfati, Y. (2010). Online news exposure and trust in the mainstream media: Exploring possible associations. American Behavioral Scientist, 54(1), 22-42.

Tsfati, Y., \& Cappella, J. N. (2003). Do people watch what they do not trust? Exploring the association between news media skepticism and exposure. Communication Research, 30(5), 504-529.

Tsfati, Y., Meyers, O., \& Peri, Y. (2006). What is good journalism? Comparing Israeli public and journalists' perspectives. Journalism, 7(2), 152-173.

Van Der Wurff, R., \& Schoenbach, K. (2014). Civic and citizen demands of news media and journalists: What does the audience expect from good journalism? Journalism \& Mass Communication Quarterly, 91(3), 433-451.

Voakes, P. S. (1997). Public perceptions of journalists' ethical motivations. Journalism \& Mass Communication Quarterly, 74(1), 23-38.

Wanta, W., \& Hu, Y. W. (1994). The effects of credibility, reliance, and exposure on media agenda-setting: A path analysis model. Journalism Quarterly, 71(1), 90-98.

Willnat, L., Weaver, D. H., \& Wilhoit, G. C. (2019). The American journalist in the digital age: How journalists and the public think about journalism in the United States. Journalism Studies, 20(3), 423-441.

Zelizer, B. (2010). About to die: How news images move the public. Oxford: Oxford University Press.

\section{About the Authors}

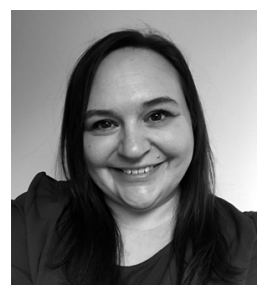

Megan Duncan (PhD, University of Wisconsin-Madison) is an Assistant Professor in the Department of Communication at Virginia Tech. She studies how audiences engage with and judge the credibility of news in emerging news environments.

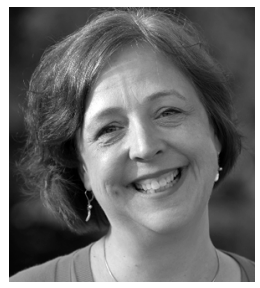

Kathleen Bartzen Culver is the James E. Burgess Chair in Journalism Ethics, an Associate Professor in the University of Wisconsin-Madison School of Journalism \& Mass Communication and Director of the Center for Journalism Ethics. Long interested in the implications of digital media on journalism and public interest communication, Culver focuses on the ethical dimensions of social tools, technological advances and networked information. She combines these interests with a background in law and free expression. 